Article

\title{
Structure, Antimicrobial Activity, Hirshfeld Analysis, and Docking Studies of Three Silver(I) Complexes-Based Pyridine Ligands
}

\author{
Ahmed M. A. Badr ${ }^{1, *}$, Assem Barakat ${ }^{2, * \mathbb{D}}$, Jörg H. Albering ${ }^{3}$, Mona M. Sharaf ${ }^{4}$, \\ Zaheer Ul-Haq ${ }^{5}$ (D) and Saied M. Soliman ${ }^{1, *(D)}$ \\ 1 Department of Chemistry, Faculty of Science, Alexandria University, P.O. Box 426, Ibrahimia, \\ Alexandria 21321, Egypt \\ 2 Department of Chemistry, College of Science, King Saud University, P.O. Box 2455, \\ Riyadh 11451, Saudi Arabia \\ 3 Technische Universität Graz, A-8010 Graz, Austria; joerg.albering@tugraz.at \\ 4 Genetic Engineering and Biotechnology Research Institute, City for Scientific Research and Technological \\ Applications, Borg El-Arab, Alexandria 21321, Egypt; mona_sharaf@hotmail.com \\ 5 Dr. Panjwani Center for Molecular Medicine and Drug Research, International Center for Chemical and \\ Biological Sciences, University of Karachi, Karachi 75270, Pakistan; zaheer.qasmi@iccs.edu \\ * Correspondence: ahmed.badr.982012@gmail.com (A.M.A.B.); ambarakat@ksu.edu.sa (A.B.); \\ Saied1soliman@yahoo.com (S.M.S.); Tel.: +20-3-5917883 (A.M.A.B.); +966-11467-5901 (A.B.); \\ Fax: +20-3-5932488 (A.M.A.B.); +966-11467-5992 (A.B.)
}

Received: 30 June 2020; Accepted: 13 July 2020; Published: 15 July 2020

\begin{abstract}
Three broad spectrum Ag(I) complexes against MDR (multi drug resistance) and ATCC standard bacteria as well as the fungus $\mathrm{C}$. albicans were presented. The three well-known structurally-related $\mathrm{Ag}(\mathrm{I})$ complexes, [Ag(pyridine-3-carboxaldhyde) $\left.{ }_{2} \mathrm{NO}_{3}\right]$, 1, $\left[\mathrm{Ag}_{3}(2 \text {-pyridone })_{3}\left(\mathrm{NO}_{3}\right)_{3}\right]_{n}, 2$, and [Ag(3-hydroxypyridine $\left.)_{2}\right]_{\mathrm{NO}_{3}}, 3$, were prepared by the direct combination of $\mathrm{AgNO}_{3}$ with the corresponding pyridine ligands in a water-ethanol mixture. $\mathbf{1}$ and $\mathbf{3}$ are molecular compounds while, $\mathbf{2}$ is a $2 \mathrm{D}$ coordination polymer with sheets bridged by strong homoleptic R2,2(8) hydrogen bonds between ligands giving the ins topology. Different contacts affecting the molecular packing in their crystal structures were computed by employing Hirshfeld analysis. Charge transferences from the ligand groups to $\operatorname{Ag}(\mathrm{I})$ were analyzed using natural population analysis. The effect of protonation and metal coordination on the tautomerism of 2-pyridone was analyzed using data from the Cambridge Structure Database (CSD). It was found that Lewis acid attachment to both $\mathrm{N}$ and $\mathrm{O}$ sites favor a state in between the two formal tautomers. All compounds were significantly more active than 17 tested commercial antibiotics against three clinically isolated strains of Ps. Aeruginosa, with $\mathbf{2}$ and $\mathbf{3}$ performing best on average against all ten tested bacterial strains but with $\mathbf{3}$ containing less Ag per weight. Finally, docking studies were carried out to unravel the inhibition mechanism of the synthesized silver(I) complexes.
\end{abstract}

Keywords: Ag(I)-pyridine complexes; Hirshfeld; ins topology; antimicrobial activity; tautomerism

\section{Introduction}

Silver-containing compounds continue to attract academic attention for their antimicrobial properties [1-8] but also for the immense variety of its coordination polymers, [9] and sometimes the two coincide [10]. A recent review is optimistic of the future role of silver in medicine, [11] while clinical studies are still not of sufficient quality to judge the practical usefulness of different silver based wound healing materials, the most common medical application [12]. 
The attractiveness lies in the low human toxicity of silver and silver ions, combined with the in-vitro antimicrobial properties that are on par, or better than conventional antibiotics. The difficulties lie in the yet sketchy knowledge of the mode(s) of action, [12] the variability of the $\mathrm{Ag}(\mathrm{I})$ coordination modes, and the solution chemistry that likely will be dominated by chlorine interactions, such as the precipitation and dissolution of $\mathrm{AgCl}(\mathrm{s})$, in biological fluids.

Silver(I) ion, and its complexes as well as their nanoparticles, have been proven to have anti-inflammatory [7], antiseptic [13], and anti-cancer activities [14]. For example, silver(I) sulfadiazine is used for treating infections during burn wounds treatment but it has been observed that silver(I) sulfadiazine has major side effects such as slowing the rate of wound healing $[15,16]$. In the literature, many $\operatorname{Ag}(\mathrm{I})$ complexes with $N$-heterocylic ligands that have significant anti-microbial actions were reported. The results disclosed that the complexes of silver(I)- $N$-heteroclyles (e.g., pyridine, pyrimidine, pyridazine, pyrazine, pyrazole, phthalazine, quinoxaline, quinazoline, and tricyclic phenazine) have high anti-microbial activity towards several strains including Pseudomonas aeruginosa, Candida albican, etc. [17-20].

The mechanism of action of the silver metal complexes as anti-microbial agent is multi-directional [21-24]. The advantage of the different pathways of the activity of silver(I) may lead to a slowdown of the bacterial drug resistance development [21-24]. One of the multi-directional activities is that silver can interact with the cell surface of the bacteria, which help it to penetrate into the cell, subsequently binding with the amino acid (thiol group in the cysteine as an example) in the DNA which interrupts the replication and transcription processes leading to death of bacteria [21-24]. An alternative pathway is that silver(I) ion can induce reactive oxygen species (ROS) production, that are known to target nucleic acids, proteins, and lipids leading to the cell death via malfunction of these biomolecules.

There is thus a good reason to continue to study the antimicrobial properties of $\mathrm{Ag}(\mathrm{I})$ compounds, while at the same time exploring their fascinating and diverse solid state and coordination chemistry [25]. In this paper we present a study of three well-known silver(I) complexes [26-28] with the closely related pyridine-type ligands pyridine-3-carboxaldehyde (also known as nicotinaldehyde), 2-pyridone (keto form of 2-hydroxy-pyridine), and 3-hydroxypyridine (3-pyridinol), see Figure 1. Synthesis, characterizations, single crystal X-ray structures, and antimicrobial screening in comparison to 17 commercial antibiotics are also described. Moreover, network topology analysis [29-31] was applied to describe the structure of the synthesized complex with 2-pyridone. In addition, the intermolecular interactions such as hydrogen bonding, $\mathrm{C}-\mathrm{H} \ldots \pi$ interactions, $\pi-\pi$ stacking, etc. play very crucial role in molecular packing of building blocks in the crystal. Hirshfeld calculations are important for quantifying these intermolecular interactions in the crystal [32-37]. In this regard, Hirshfeld quantitative analysis for the three complexes was performed.

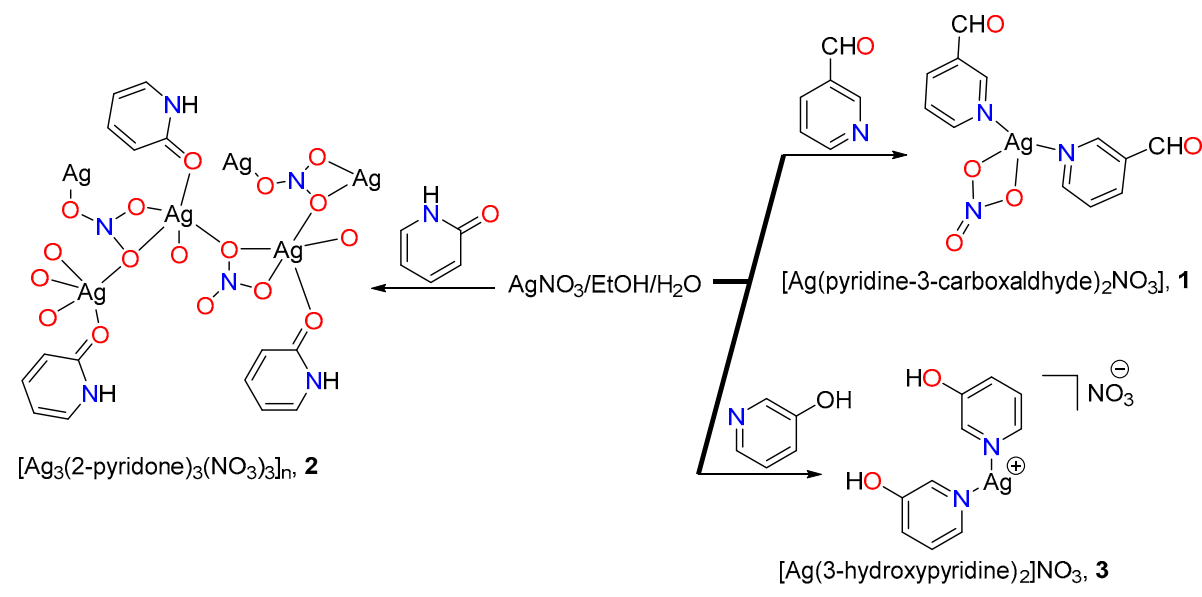

Figure 1. The representative schematic presentation for the synthesis of the target complexes 1-3. 


\section{Materials and Methods}

\subsection{General Methods}

All reagents used in this research are technical grade and utilized without purification. All physicochemical measurements are provided in the supplementary information.

\subsection{Synthesis}

All silver(I) complexes were synthesized by employing a self-assembly approach. To a solution of $\mathrm{AgNO}_{3}(0.17 \mathrm{~g}, 1.0 \mathrm{mmol})$ in $\mathrm{H}_{2} \mathrm{O}(10 \mathrm{Ml}$, deionized), then, an ethanolic solution of pyridine-3-carboxaldhyde (0.19 mL, 2.0 mmol), 2-pyridone (0.095 g, $1.0 \mathrm{mmol})$ or 3-hydroxypyridine $(0.19 \mathrm{~g}, 2.0 \mathrm{mmol})$ added drop by drop with stirring. The solution was kept at ambient for few days to give colorless crystals of the target complexes. The crystals were filtered off, washed with small amount of ethanol, and dried in air. FTIR and NMR spectra of the three complexes are given in Figures S1 and Figure S2 (Supplementary data), respectively.

[Ag(pyridine-3-carboxaldhyde) ${ }_{2} \mathrm{NO}_{3}$ ], 1 [26], Yield: $0.15 \mathrm{~g}, 80 \%$ with respect to the ligand. (\%): Calc.: C, 37.52; H, 2.62; N, 10.94; Ag, 28.08. Found: C, 37.49; H, 2.63; N, 10.94; Ag, 28.10. ${ }^{1} \mathrm{H}$ NMR (DMSO- $\left.d_{6}, 500 \mathrm{MHz}\right): \delta 7.64(\mathrm{t}, 1 \mathrm{H}$ at C-5), $8.24(\mathrm{~d}, 1 \mathrm{H}$ at C-4), $8.82(\mathrm{~d}, 1 \mathrm{H}$ at C-6), $9.06(\mathrm{~s}, 1 \mathrm{H}$ at C-2) and 10.08 (s, $1 \mathrm{H}$ at C-7). ${ }^{13} \mathrm{C}$ NMR (DMSO- $d_{6}, 125 \mathrm{MHz}$ ): $\delta 125.16,125.18$ (C-5), 131.90, 131.95 (C-3), 136.89, 137.14 (C-4), 152.10, 152.22 (C-2), 155.40, 155.40 (C-6), 192.23, 192.24, 193.17, 193.82 (C-7 of aldehyde).

[ $\left.\mathrm{Ag}_{3}(2 \text {-pyridone })_{3}\left(\mathrm{NO}_{3}\right)_{3}\right]_{\mathrm{n}}, 2$ [27], Yield: $0.196 \mathrm{~g}, 74 \%$ with respect to the ligand. (\%): Calc.: $\mathrm{C}$, 22.66; H, 1.90; N, 10.57; Ag, 40.71. Found: C, 22.67; H, 1.91; N, 10.57; Ag, 40.70.

${ }^{1} \mathrm{H}$ NMR (DMSO- $\left.d_{6}, 500 \mathrm{MHz}\right): \delta 6.20(\mathrm{t}, 1 \mathrm{H}, \mathrm{H}-4), 6.33(\mathrm{~d}, 1 \mathrm{H}, \mathrm{H}-3), 7.39-7.41$ (m, $\left.2 \mathrm{H}, \mathrm{H}-5, \mathrm{H}-6\right)$, $11.61\left(\mathrm{~s}, 1 \mathrm{H}, \mathrm{NH}\right.$, exchangeable with $\mathrm{D}_{2} \mathrm{O}$ ); ${ }^{13} \mathrm{C}$ NMR (DMSO- $\left.d_{6}, 125 \mathrm{MHz}\right): \delta 106.57,106.81$ (C-5), $119.59,119.83$ (C-3), 137.04, 137.33 (C-6), 141.65, 141.89(C-4), 163.16 (C=O).

[Ag(3-hydroxypyridine) ${ }_{2}$ ] $\mathrm{NO}_{3}, 3$ [28], Yield: $0.31 \mathrm{~g}, 86 \%$ with respect to the ligand. (\%): Calc.: C, 33.36; H, 2.80; N, 11.67; Ag, 29.96. Found: $\mathrm{C}, 33.36 ; \mathrm{H}, 2.81 ; \mathrm{N}, 11.66 ; \mathrm{Ag}, 29.97 .{ }_{1} \mathrm{H}$ NMR (DMSO- $d_{6}, 500$ MHz): $\delta$ 7.2-7.4 (m, 2 H, H-4, H-5), 8.01 (d, 1 H, H-5), 8.12 (d, H, H-2), 10.05 (s, $1 \mathrm{H}, \mathrm{OH}$, exchangeable with $\mathrm{D}_{2} \mathrm{O}$ ); ${ }^{13} \mathrm{C}$ NMR (DMSO- $d_{6}, 125 \mathrm{MHz}$ ): $\delta$ 123.26, 123.68 (C-4), 125.00, 125.37 (C-5), 139.82, 139.09 (C-2), 141.25, 141.49 (C-6), 154.50 (C-3).

\subsection{X-Ray Crystallography}

Experimental details of the crystallographic measurements for the studied complexes are provided in the supplementary information [38-40]. The low temperature crystallographic structural data at 100 (2) $\mathrm{K}$ for the studied $\mathrm{Ag}(\mathrm{I})$ complexes were deposited at CCDC with numbers 1,062,878-1,062,880. The topology analyses were performed using Crystal Explorer 17.5 program [41].

\subsection{Computational Details}

The amount of charge transferred from the ligand groups to the $\mathrm{Ag}(\mathrm{I})$ in complexes 1-3 were calculated using NBO 3.1 [42] program with the aid of Gaussian 09 program package [43]. For this task, the $\omega$ B97XD DFT method in combination with 6-311G $(\mathrm{d}, \mathrm{p})$ basis sets for nonmetal atoms and LANL2DZ basis set for Ag were used.

\subsection{Testing of Antimicrobial Activity}

The full details about the anti-microbial protocol are provided in the supplementary information [44].

\subsection{Methodology for Molecular Docking}

The binding mechanism of the three silver(I) complexes was investigated at molecular level using molecular docking. To validate and specify the target for anti-bacterial and anti-fungal potential of 
these compounds, seven different protein targets i.e., $N$-myristoyl transferase (PDB ID 1IYL) [45], dihydrofolate reductase (DHFR) (PDB ID 4HOF) [46] from C. albicans were selected as fungal targets, while dihydrofolate reductase (PDB ID 3FYV) [47], gyrase B (PDB ID 4URM) [48] from S. aureus, DNA (PDB ID 1BNA) [49] thymidylate kinase of P. Aeruginosa (PDB ID 3UWK) [50], and undecaprenyl diphosphate synthase (PDB ID 4H2M) [51] from E. coli were selected based on their direct role in the drug resistance. Crystal structures of all these proteins in complex with their cognate ligand were retrieved from the Protein Data Bank. All proteins were prepared, protonated, charged, and minimized by structure preparation module in MOE [52]. Solvent molecules were removed as required. The compounds were built using the builder module in MOE. Complexes were further charged and minimized by MMFF94x forcefield [53]. For docking, an induced fit docking protocol was used with default MOE docking parameters i.e., Triangle Matcher Algorithm with two rescoring functions London dG and GBVI/WSA dG. For each complex a total thirty conformations were generated and saved in mdb format.

\section{Results and Discussion}

\subsection{Crystal Structures}

All crystallographic measurements were performed using graphite monochromated MoKa radiation at 100(2) K. The structure of complexes $\mathbf{1}$ and $\mathbf{3}$ agrees well with the previously reported X-ray data shown in Figure 2 [26,28]. All relevant crystallographic data as well as selected interatomic distances and bond angles can be taken from Tables S1-S4 (Supplementary data). Interestingly, the low temperature $\mathrm{X}$-ray structure of $\left[\mathrm{Ag}\left(2 \text {-pyridone) } \mathrm{NO}_{3}\right]_{n} ;(2)\right.$ complex showed some variations compared to the previously reported room temperature (293(2) K) data [27]. Hence, its structure will be described in some details in this publication. The asymmetric unit of $\left[\mathrm{Ag}\left(2 \text {-pyridone) } \mathrm{NO}_{3}\right]_{n}\right.$; (2) contains three independent $\mathrm{AgL}\left(\mathrm{NO}_{3}\right)$ complexes (Figure 2), which differ slightly by their Ag-O(NO bond distances and $\mathrm{O}-\mathrm{Ag}-\mathrm{O}$ bond angles. The coordination geometry of $\mathrm{Ag}(\mathrm{I})$ have one short $\mathrm{Ag}-\mathrm{O}$ bond (2.307-2.316(4) $\AA$ ) to the organic ligand and longer bonds (2.533(4) $\AA$, Ag3-O9, to 2.666(5) $\AA$, Ag2-O12) to the nitrate anions. On other hand, the main difference between the newly reported structure of $\mathbf{2}$ with the previously reported data by Bowmaker and coworkers is that the asymmetric unit of the latter comprised one $\mathrm{AgL}\left(\mathrm{NO}_{3}\right)$ unit in which the corresponding Ag-O distances are 2.315(6) and $2.588(8)$ to $2.715(10) \AA$, respectively.

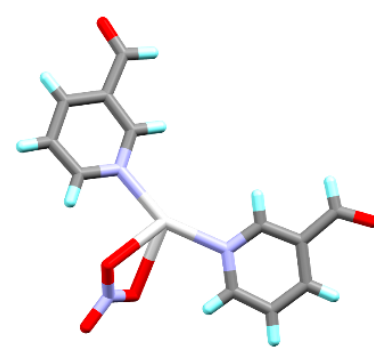

1

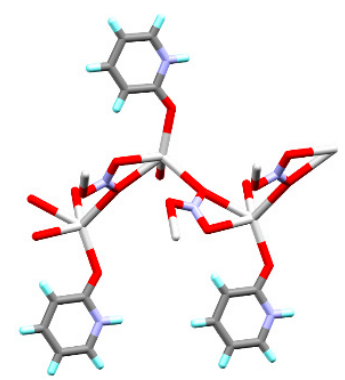

2

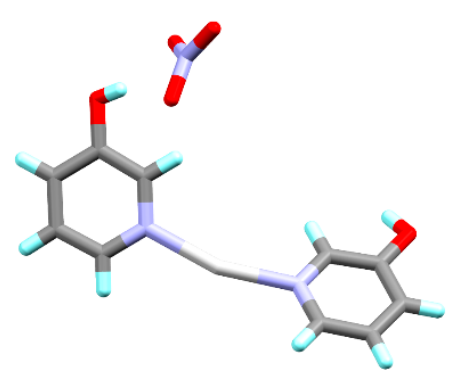

3

Figure 2. The X-ray structure of complexes 1-3.

The crystal structure of $\left[\mathrm{Ag}\left(2 \text {-pyridone) } \mathrm{NO}_{3}\right]_{\mathrm{n}}\right.$ is built up by a strongly folded 2D-infinite network of silver cations and nitrate anions parallel to the $a b$ plane of the unit cell (Figure S3; Supplementary data) where the coordination geometry of the $\mathrm{Ag}(\mathrm{I})$ could be simply described as distorted tetrahedral as shown in Figure S4 (Supplementary data). These are interconnected by the 2-pyridone ligands by formation of two strong hydrogen bonds with the $R 2,2(8)$ pattern between two neighboring ligands (N-H...O distances: N-H: $0.879 \AA$ А, H...O: $1.922 \AA$ for O3-H1, $1.924 \AA$ for O2-H3B and $1.932 \AA$ for O1-H2B) as shown in Figure 3. This is a common motif for lactam dimers [54]. The structure is best understood 
as a 3D net with the ins-topology, illustrated in Figure 4. The topology is binodal, containing one type of 3-connected node and one type of 4-connected node. This topology is rather rare, but has also been found in the coordination polymer $\left[\mathrm{Ag}_{3}\right.$ (hexamethylenetetramine) $\left.{ }_{2}\right]\left[\mathrm{ClO}_{4}\right]_{3} \cdot 2 \mathrm{H}_{2} \mathrm{O}[55]$.

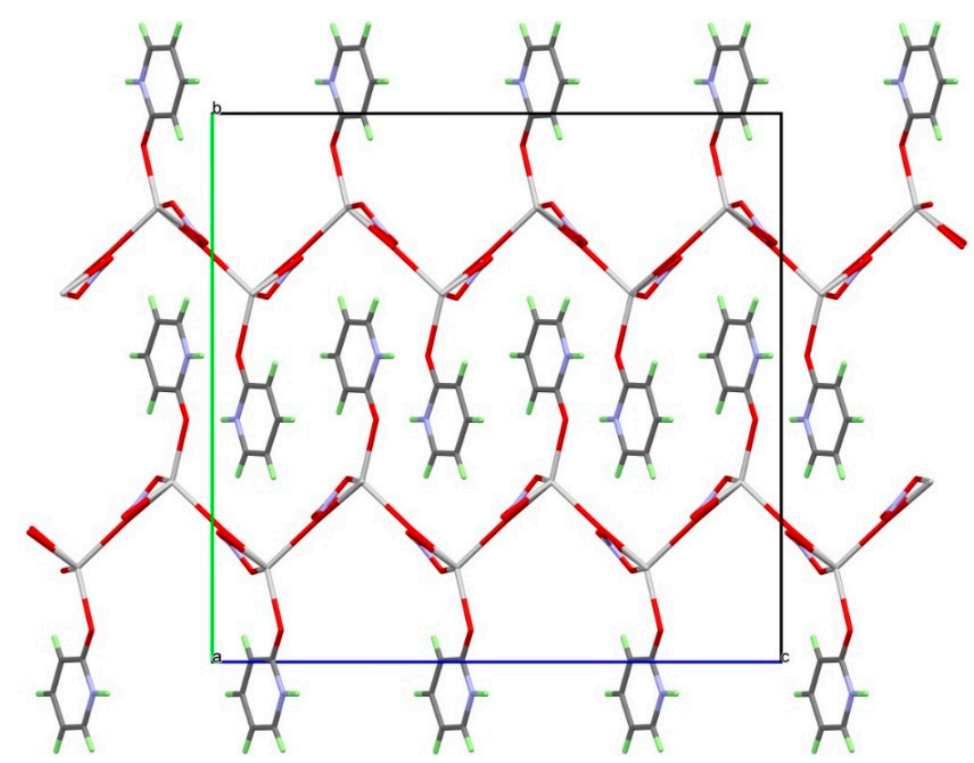

Figure 3. Projection of the structure of $\left[\mathrm{Ag}(2 \text {-pyridone }) \mathrm{NO}_{3}\right]_{\mathrm{n}}$ along the crystallographic $a$-axis.
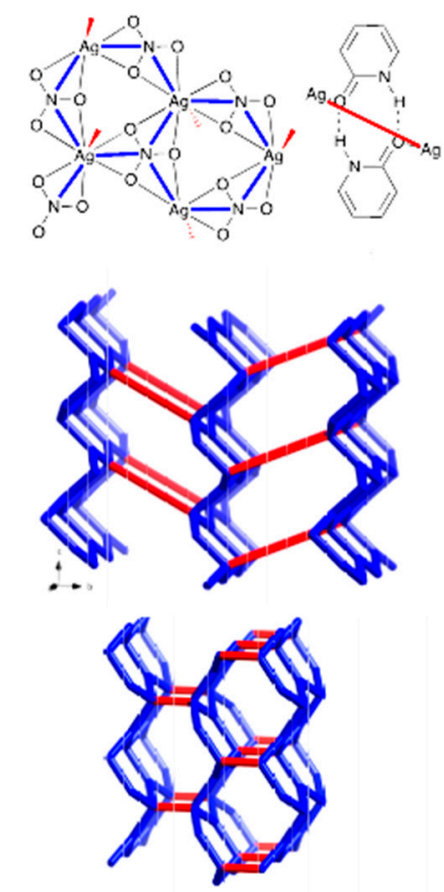

Figure 4. Node assignment (top) and resulting ins-net in $\left[\mathrm{Ag}\left(2 \text {-pyridone) } \mathrm{NO}_{3}\right]_{n} ; 2\right.$ (center) and the ideal ins-net (bottom).

Indeed, the ADDSYM option of the software package PLATON suggests a transformation to another unit cell with only $1 / 3$ of the initial volume and thus only one formula unit per asymmetric unit [27]. However, even if this may correspond to the network topology, this is not the correct description of the symmetry of the studied complex. A refinement with the smaller unit cell led to implausible atomic displacement parameters, high standard deviations of the positional parameters, and much higher R-values. 


\subsection{Tautomerism in 2-Pyridone/2-Hydroxy-Pyridine Systems}

It has been agreed for quite some time that it is the 2-pyridone form and not the tautomer 2-hydroxy-pyridine that is the most stable form of this molecule in the solid state, but in the gas phase 2-hydroxy-pyridine is favored and in solution sometime delicate equilibriums exist [56,57]. Depending on substitution pattern, similar molecules may prefer either forms, but a search of the Cambridge Structure Database (CSD) showed that the 2-pyridone form is prevalent, as illustrated in the plot of C1-O1 versus C1-C2 shown in Figure 5.

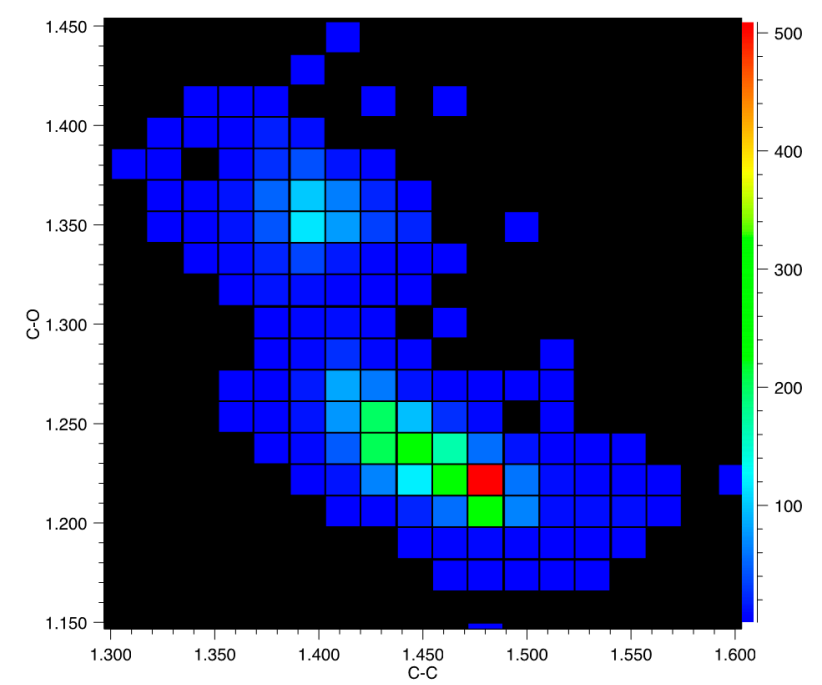

Figure 5. Analysis of the 2-pyridone/2-hydroxy-pyridine tautomerism in purely organic compounds in the Cambridge Structure Database (CSD). Using the atom numbering in Figure 1, we have plotted the distances of $\mathrm{C} 1-\mathrm{O} 1$ versus $\mathrm{C} 1-\mathrm{C} 2$ and the colors represent number of hits in the database.

It is clear that there is a preference for C-C distance of $1.48 \AA$ with a C-O distance of $1.22 \AA$, thus the 2-pyridone form, but there is also a much smaller minimum at C-C distance of $1.39 \AA$ with a C-O distance of $1.35 \AA$ corresponding to the 2-hydroxy-pyridine form. In [Ag(2-pyridone) $\left.\mathrm{NO}_{3}\right]_{\mathrm{n}}$ complex, both $\mathrm{N}$ and $\mathrm{O}$ are connected to Lewis acids $\left(\mathrm{H}^{+}\right.$and $\left.\mathrm{Ag}^{+}\right)$and also the $\mathrm{C}-\mathrm{C}$ distances: $1.425-1.436 \AA$; and C-O distances: $1.266-1.273 \AA$, give no clear clue about whether this is the keto- or enol-form. In fact, looking at Figure 5 it seems that it falls right in the area that could be considered to correspond to the transition state and indeed the transition state of the tautomerization has been shown theoretically to go through a similar dimerization [57].

\subsection{Analysis of Molecular Packing}

The different Hirshfeld surfaces of the three complexes are collected in Figure 6. In the studied $\mathrm{Ag}(\mathrm{I})$ complexes, the molecules are packed differently in the crystal structure and the possible contacts are presented in Figure 7. 

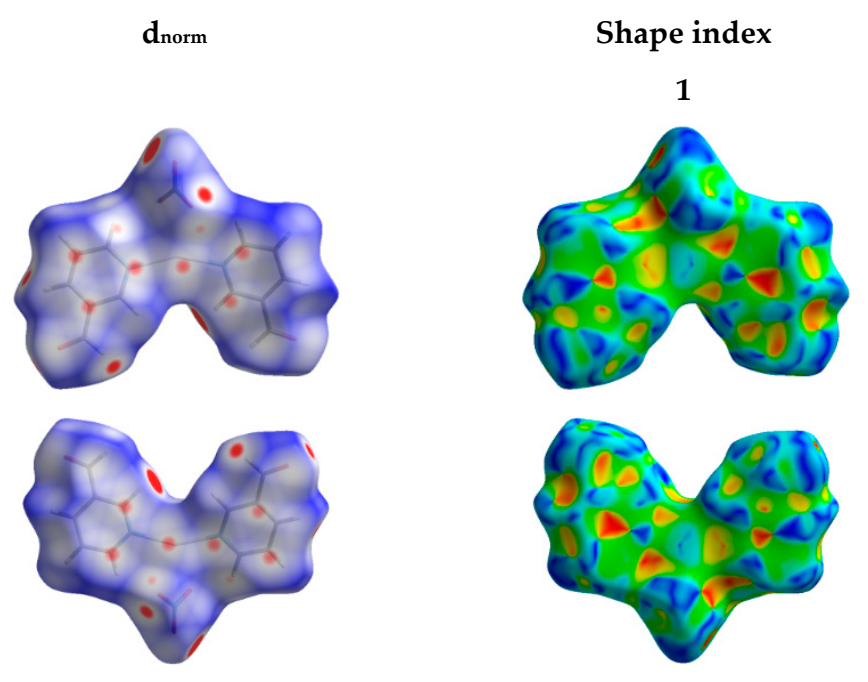

\author{
Curvedness
}
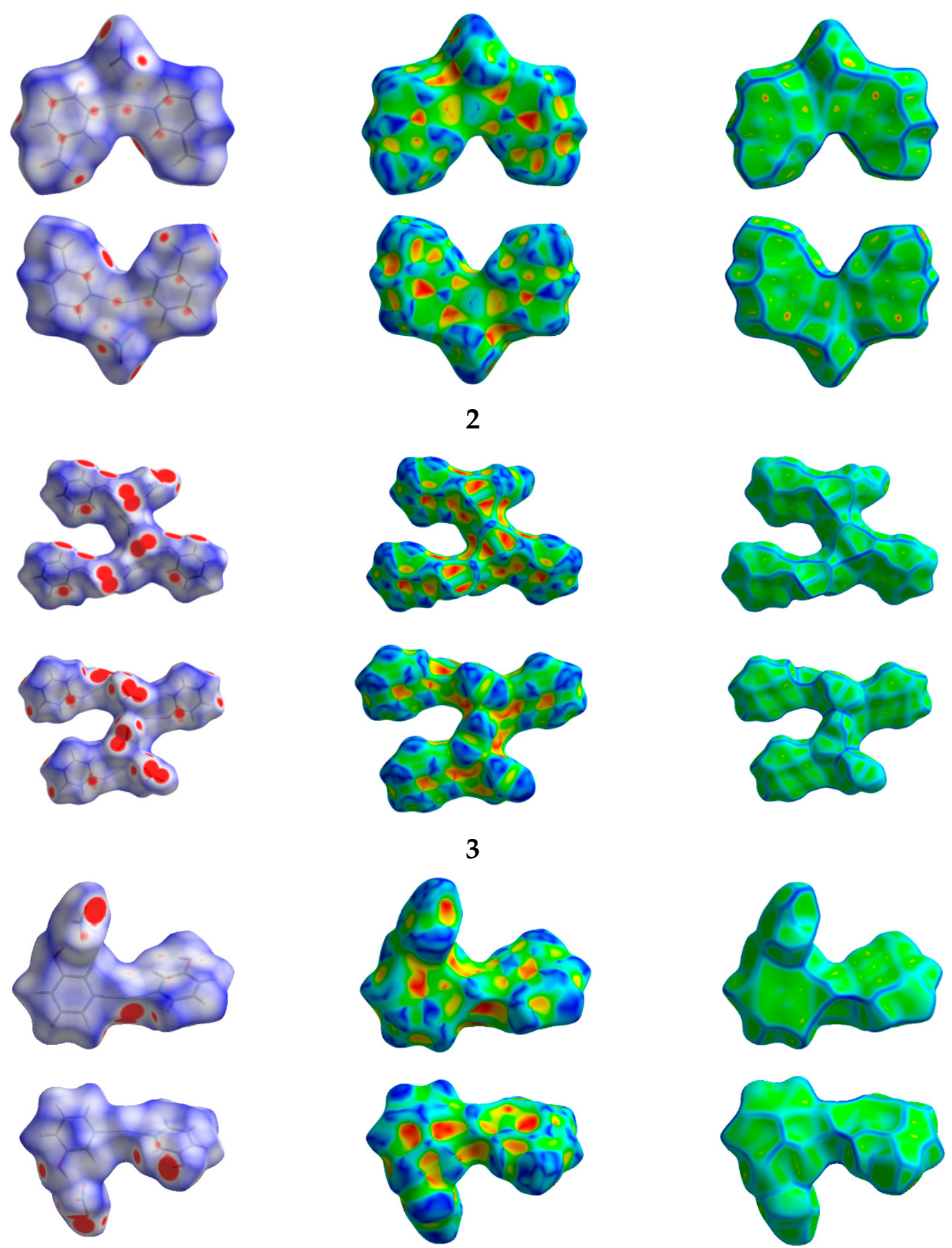

Figure 6. Hirshfeld analyses of $\left.[\mathrm{Ag} \text { (pyridine-3-carboxaldhyde })_{2} \mathrm{NO}_{3}\right]$; (1), $\left[\mathrm{Ag}_{3}(2 \text {-pyridone })_{3}\left(\mathrm{NO}_{3}\right)_{3}\right]$; (2), and $\left[\mathrm{Ag}(3 \text {-hydroxypyridine })_{2}\right] \mathrm{NO}_{3} ;$ (3) complexes. 


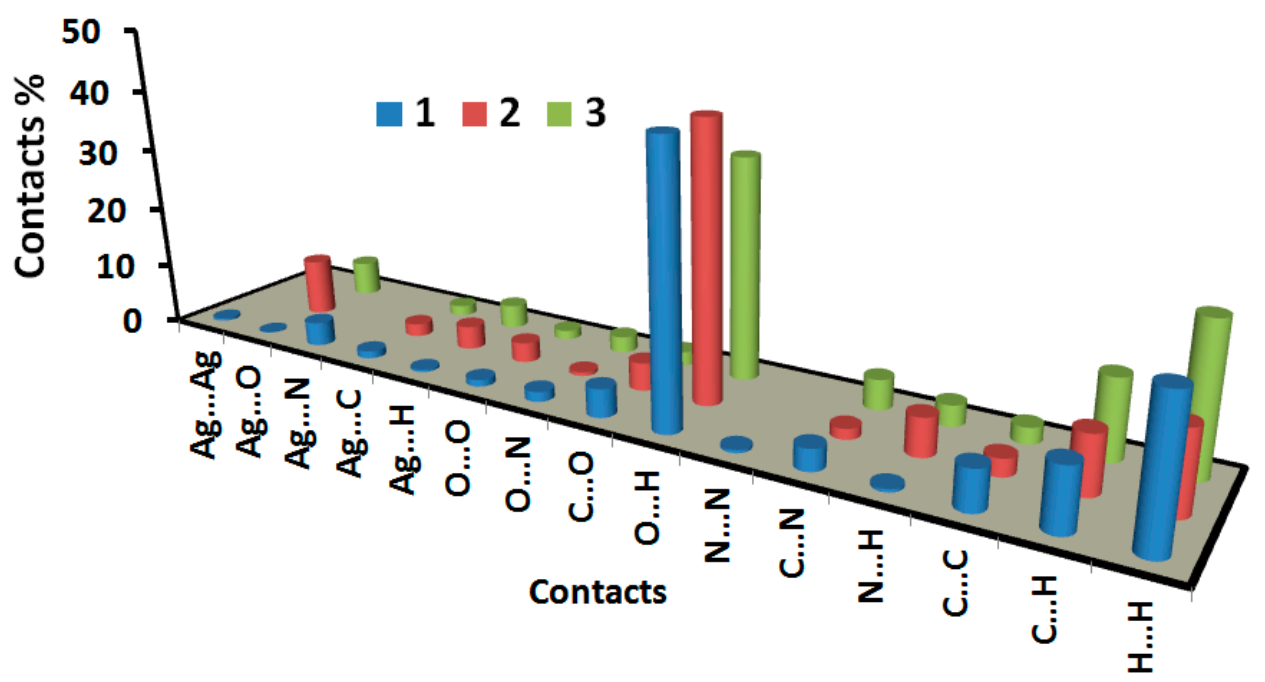

Figure 7. Different contacts in $\left[\mathrm{Ag}\right.$ (pyridine-3-carboxaldhyde) $\left.\left.{ }_{2} \mathrm{NO}_{3}\right] ;(\mathbf{1}),\left[\mathrm{Ag}_{3} \text { (2-pyridone }\right)_{3}\left(\mathrm{NO}_{3}\right)_{3}\right]$; (2) and $\left[\mathrm{Ag}(3 \text {-hydroxypyridine })_{2}\right] \mathrm{NO}_{3} ;$; (3) complexes.

It is clear from Figure 7 that the $\mathrm{O} \ldots \mathrm{H}$ interactions contributed heavily in the molecular packing of the three complexes. The parentages of the $\mathrm{O} \ldots \mathrm{H}$ interactions are $43.7,43.8$, and $35.6 \%$ for complexes 1-3, respectively. The decomposed $d_{\text {norm }}$ maps and fingerprint plots shown in Figure 8 revealed the importance of these interactions in the molecular packing.

1
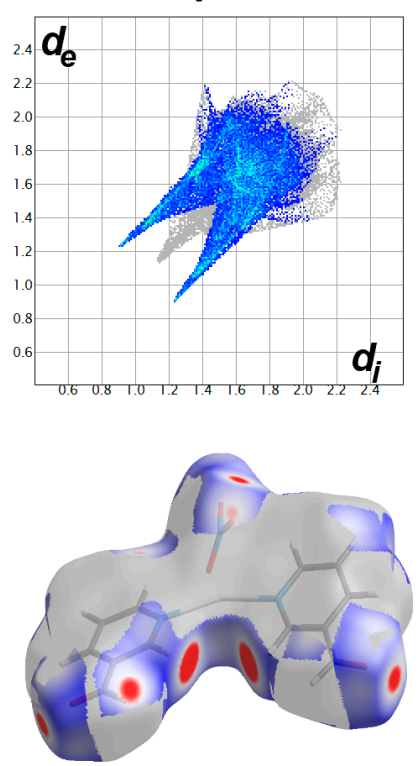

2
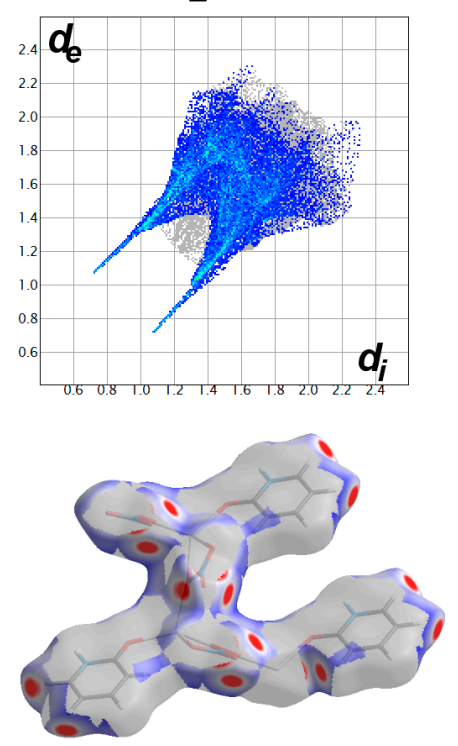

3
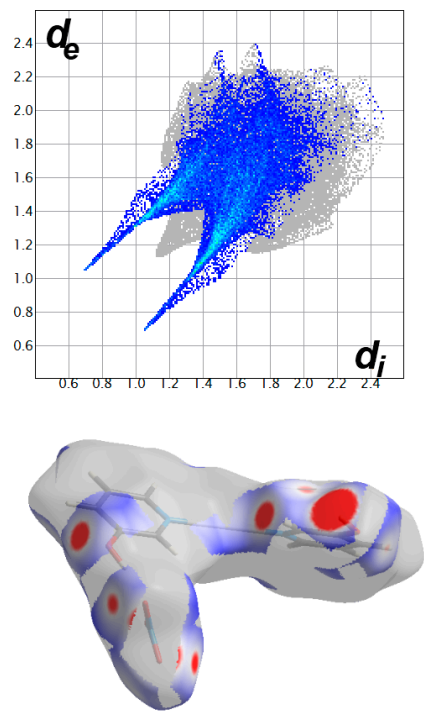

Figure 8. The fingerprint (upper) and $d_{\text {norm }}$ maps (lower) of the $\mathrm{O} \ldots \mathrm{H}$ contacts. Sharp spikes in the fingerprint plot and red spots in $\mathrm{d}_{\text {norm }}$ maps are strong pieces of evidence on the importance of $\mathrm{O} \ldots \mathrm{H}$ contacts in the molecular packing.

The $\pi-\pi$ stacking interactions are another interesting feature of molecular packing that was observed using Hirshfeld surface analysis. It is clear from Figure 9 that all evidences for the $\pi-\pi$ contacts such as red spots in $d_{\text {norm }}$ and blue/red triangles in the shape index map were achieved. In addition, there is appropriate amount of $C \ldots C$ contacts in the three complexes as indicated from the fingerprint plot. The C .. C contact percentages are $6.4,2.8$, and $2.6 \%$ for complexes $1-3$, respectively. 

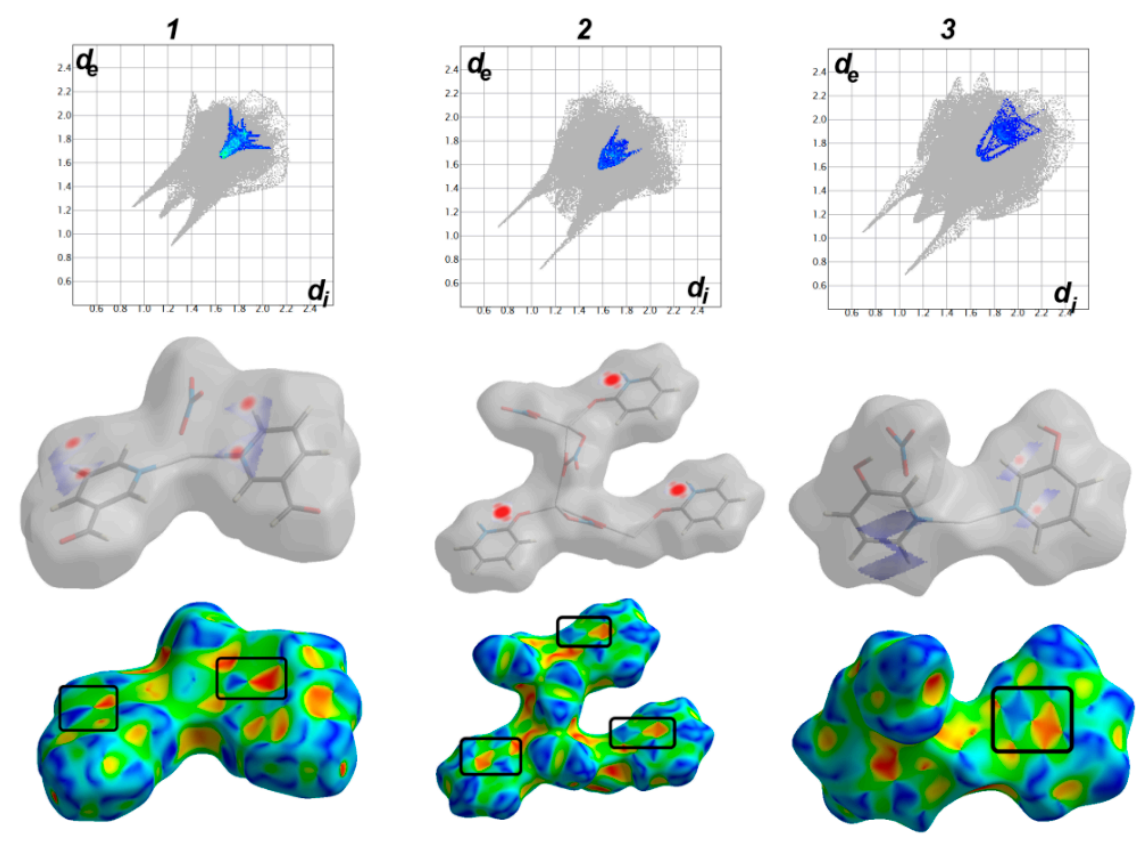

Figure 9. The fingerprint (upper), $d_{\text {norm }}$ maps (middle), and shape index (lower) of the C .. C contacts.

In addition to these intermolecular interactions, the Hirshfeld surfaces detected very well the polymeric nature of complex 2 via Ag-O bonding with the neighboring complex units (Figure 10B). Also, complex 1 showed significant amount of short Ag ... N interactions (3.9\%) with the neighboring complex units (Figure 10A), while in complex 3 some significant $\mathrm{Ag} \ldots \mathrm{C}(1.7 \%)$ and $\mathrm{Ag} \ldots \mathrm{O}(5.7 \%)$ interactions were detected (Figure 10C,D). It is worth to note that the Ag $\ldots$ C interactions have less significance in complexes 1 and 2 compared to 3 .
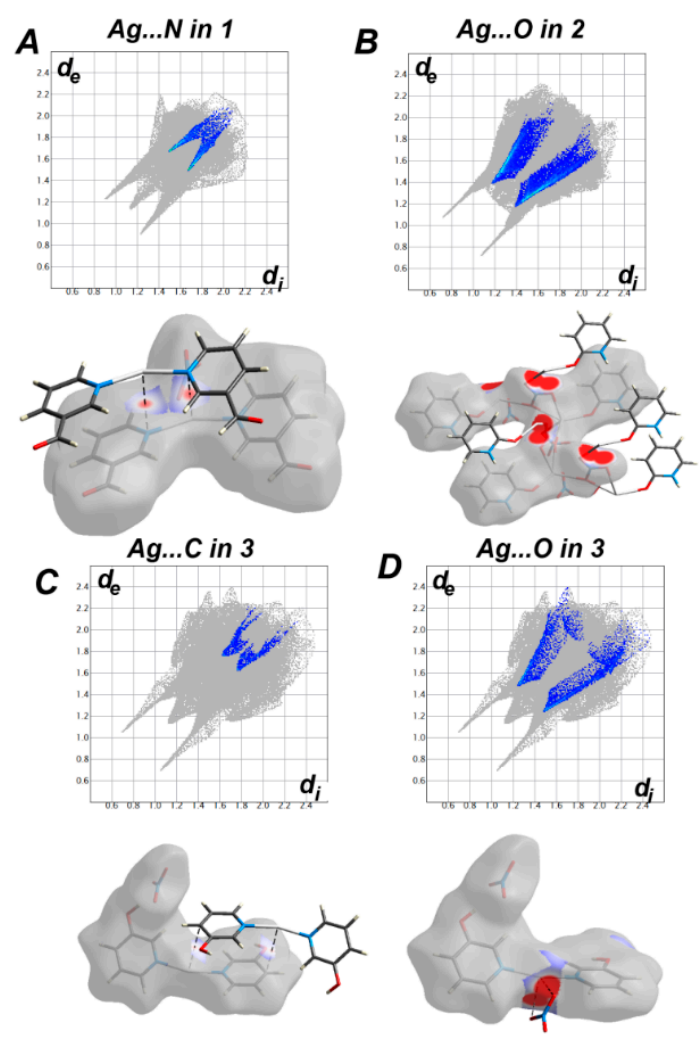

Figure 10. The rest of the most important contacts in complexes 1-3. 


\subsection{Natural Charge Analysis}

The calculated natural charges of $\mathrm{Ag}$ and ligand groups for the [Ag(pyridine-3-carboxaldhyde) $\left.{ }_{2} \mathrm{NO}_{3}\right]$; (1), $\left[\mathrm{Ag}_{3}(2 \text {-pyridone })_{3}\left(\mathrm{NO}_{3}\right)_{3}\right] ;$ (2), and [Ag(3-hydroxypyridine) $\left.)_{2}\right] \mathrm{NO}_{3} ;(3)$ complex units are listed in Table 1. It is clear that the net charge of the nitrate group is close to -1 in complex 3 which comprised an ionic nitrate, which is weakly coordinated to $\mathrm{Ag}(\mathrm{I})$ ion. The amount of electrons transferred to $\mathrm{Ag}(\mathrm{I})$ in this case is only $0.0358 \mathrm{e}$. In contrast, the amount of electrons transferred from the nitrate group to $\mathrm{Ag}(\mathrm{I})$ ion in complexes 1 and $\mathbf{2}$ are higher. The amounts of electron density transferred are 0.1635 and $0.1936 \mathrm{e}$, respectively indicating strongly coordinated nitrate to the silver ion. The pyridine ligand groups transferred $0.1071,0.0762$, and 0.1395 e in complexes 1-3, respectively. As a result, the charges at silver atom were reduced to $0.6222,0.7284$, and 0.6852 , respectively.

Table 1. The net natural charges at ligand groups and Ag.

\begin{tabular}{cccc}
\hline Metal/Ligand & $\mathbf{1}$ & $\mathbf{2}$ & $\mathbf{3}$ \\
\hline $\mathbf{A g}$ & 0.6222 & 0.7284 & 0.6852 \\
Py-ligand & 0.1071 & 0.0762 & 0.1395 \\
NO $_{3^{-}}$ & -0.8365 & -0.8046 & -0.9642 \\
\hline
\end{tabular}

\subsection{Antimicrobial Activity}

Previous studies showed that silver(I) metal complexes-based different $N$-heterocycles such as imidazole, 1,2,4-triazole and tetrazole were active against two strains including Ps. aeruginosa and S. aureus and more potent (ca. 4-8 folds) better than the silver nitrate $\left(\mathrm{AgNO}_{3}\right)$ as positive control [58]. Also, silver(I)-imidazole and silver(I)-L-histidine polymer complexes were shown to have an equal potency of the studied microbial strains S. aureus and Ps. aeruginosa (MIC 15.7 and $12.5 \mu \mathrm{g} / \mathrm{mL}$ ), on the other hands, silver(I)-1,2,3-triazole polymer complex had no effect on the bacteria [59]. Several examples of the silver metal complexes based on nicotinate compounds have been explored by our research group previously [60], where $\left[\mathrm{Ag}(\text { isonicotinamide })_{2}-\mu-\mathrm{O}, \mathrm{O}^{\prime}\left(\mathrm{NO}_{3}\right)\right]_{2}$ and $\left[\mathrm{Ag} 2-\mu-\mathrm{O}, \mathrm{O}^{\prime}(2 \text {-aminonicotinium })_{2}-\left(\mathrm{NO}_{3}\right)_{2}\right]_{\mathrm{n}}$ exhibited a remarkable effect towards Ps. aeruginosa with MIC ranged $2-8 \mu \mathrm{g} / \mathrm{mL}$, another example for the silver metal complex such as $\left[\mathrm{Ag}(\text { ethylnicotinate })_{2}\right]\left(\mathrm{NO}_{3}\right)$ showed against two strains including $S$. aureus and S. pyogenes ( $\mathrm{MIC}=4-16$ and $2-4 \mu \mathrm{g} / \mathrm{mL}$, respectively). [Ag(ethylisonicotinate) ${ }_{2}\left(\mathrm{NO}_{3}\right)$ ], [Ag(methylisonicotinate $\left.)_{2}\left(\mathrm{H}_{2} \mathrm{O}\right)\right]\left(\mathrm{NO}_{3}\right)$, and $\left.[\mathrm{Ag} \text { (ethylnicotinate })_{2}\right]\left(\mathrm{NO}_{3}\right)$ possessed high efficacy towards P. mirabilis (MIC 1-16 $\mu \mathrm{g} / \mathrm{mL}$ ). Also, we have explored silver(I)-based pyridine complexes and the anti-microbial activity against $S$. lutea and $M$. lutea, which provided interesting and promising results with the MIC $=2$ and $4 \mu \mathrm{g} / \mathrm{mL}$, respectively [44].

In this paper we introduced another group of silver(I) pyridine complexes with relatively high biological activity against a broad spectrum of MDR (multi drug resistance) and ATCC standard bacteria as well as the fungus C. albicans. The Minimum Inhibition Concentrations (MIC) of the tested compounds were tested and 17 antibiotics were used for the activity comparison. The detailed results are given in Table 2 and presented graphically in Figure 11. One of the advantages of this set of silver complexes is its broad-spectrum activity against MDR (multi drug resistance) bacteria isolated from diabetic foot ulcers as well as the ATCC standard bacteria with different action ranging from MIC $=4 \mu \mathrm{g} / \mathrm{mL}$ for compound 2 against Ps. Aeruginosa to MIC $=64 \mu \mathrm{g} / \mathrm{mL}$ for compound 1 against $K$. pneumoniae and E. Coli. An additional advantage of silver compounds is that they, in contrast with antibiotics in general, are active against fungi. Thus complexes 1-3 were active against the yeast $C$. albicans (See Table 2). When looking to these data, we also need to consider the different silver contents of the three compounds. These being by weight $28 \%$ for $1,41 \%$ for 2 and $30 \%$ for 3 . The best action is for 2 against Ps. Aeruginosa with MIC value of $4 \mu \mathrm{g} / \mathrm{mL}$. 
Table 2. Minimum inhibitory concentration (MIC) for complexes 1-3 compared with reference antibiotic drugs. (MIC $\geq 256$ indicated no activity).

\begin{tabular}{|c|c|c|c|c|c|c|c|c|c|c|c|}
\hline \multirow{3}{*}{ Antibiotic } & \multicolumn{3}{|c|}{ Gram-Positive Bacteria } & \multicolumn{6}{|c|}{ Gram-Negative Bacteria } & \multicolumn{2}{|r|}{ Fungi } \\
\hline & \multicolumn{11}{|c|}{ MIC $(\mu \mathrm{g} / \mathrm{mL})$} \\
\hline & S. lutea ${ }^{1}$ & M. luteus ${ }^{2}$ & S. aureus ${ }^{3}$ & E. coli $^{4}$ & K. pneumoniae ${ }^{2}$ & Ps. aeruginosa ${ }^{1}$ & Ps. aeruginosa $a^{2}$ & Ps. aeruginosa ${ }^{3}$ & P. mirablis ${ }^{2}$ & E. cloacae $^{2}$ & C. albicans ${ }^{2}$ \\
\hline Amikacin & 4 & 8 & 4 & 8 & $>256$ & 12 & 32 & $>256$ & 64 & $>256$ & - \\
\hline Gentamicin & 16 & 16 & 16 & 4 & 32 & 24 & 24 & 96 & 192 & $>256$ & - \\
\hline Streptomycin & 16 & 64 & 12 & 6 & 64 & 16 & 12 & 128 & 128 & $>256$ & - \\
\hline Amoxicillin & 8 & 24 & 8 & 32 & $>256$ & $>256$ & 16 & 192 & 192 & 128 & - \\
\hline Ampicillin & 64 & 16 & 4 & 24 & $>256$ & 8 & 8 & 96 & 128 & 96 & - \\
\hline Cephradine $^{\mathrm{i}}$ & 48 & 64 & 16 & 24 & 192 & 128 & 32 & 192 & 192 & $>256$ & - \\
\hline Cefuroximeii $^{\mathrm{ii}}$ & 32 & 32 & 8 & 16 & 128 & 64 & 16 & 128 & 96 & 128 & - \\
\hline Cefoperazone $\mathrm{e}^{\mathrm{iii}}$ & 16 & 16 & 6 & 12 & 96 & 8 & 16 & 96 & 32 & 48 & - \\
\hline Cefepime $^{\text {iv }}$ & 24 & 8 & 4 & 4 & 64 & 32 & 8 & 48 & 24 & 32 & - \\
\hline Imipenem & 8 & 32 & 2 & 3 & $>256$ & $>256$ & 64 & 96 & $>256$ & 16 & - \\
\hline Meropenem & 32 & 16 & 2 & 2 & 192 & 128 & 48 & 64 & 128 & 12 & - \\
\hline Azithromycin & 16 & 16 & 12 & 12 & 64 & 128 & 64 & 128 & 48 & 64 & - \\
\hline Clarithromycin & 24 & 24 & 16 & 8 & 32 & 96 & 48 & 96 & 32 & 32 & - \\
\hline $\begin{array}{c}\text { Nalidixic } \\
\text { acid }^{\mathrm{i}}\end{array}$ & 8 & 32 & 24 & 4 & 128 & 64 & 48 & 128 & $>256$ & $>256$ & - \\
\hline Ciprofloxacini & 4 & 24 & 4 & 6 & 32 & 48 & 24 & 64 & 64 & 128 & - \\
\hline Levofloxacin ${ }^{\text {iii }}$ & 16 & 16 & 3 & 8 & 16 & 32 & 16 & 32 & 32 & 32 & - \\
\hline Vancomycin & 32 & 24 & 32 & 4 & 128 & 64 & 32 & 128 & 48 & 64 & - \\
\hline 1 & 32 & 8 & 32 & 16 & 64 & 8 & 8 & 8 & 32 & 64 & 6 \\
\hline 2 & 12 & 16 & 8 & 32 & 32 & 4 & 4 & 4 & 16 & 8 & 8 \\
\hline 3 & 12 & 16 & 16 & 16 & 32 & 8 & 8 & 8 & 16 & 32 & 32 \\
\hline
\end{tabular}

${ }^{1}$ ATCC $10,031{ }^{2}$ Clinical $^{3}$ ATCC $6538 p,{ }^{4}$ ATCC 8739 ; Roman superscript numbers indicate the generation of the antibiotic. Lower values indicate higher activity. 


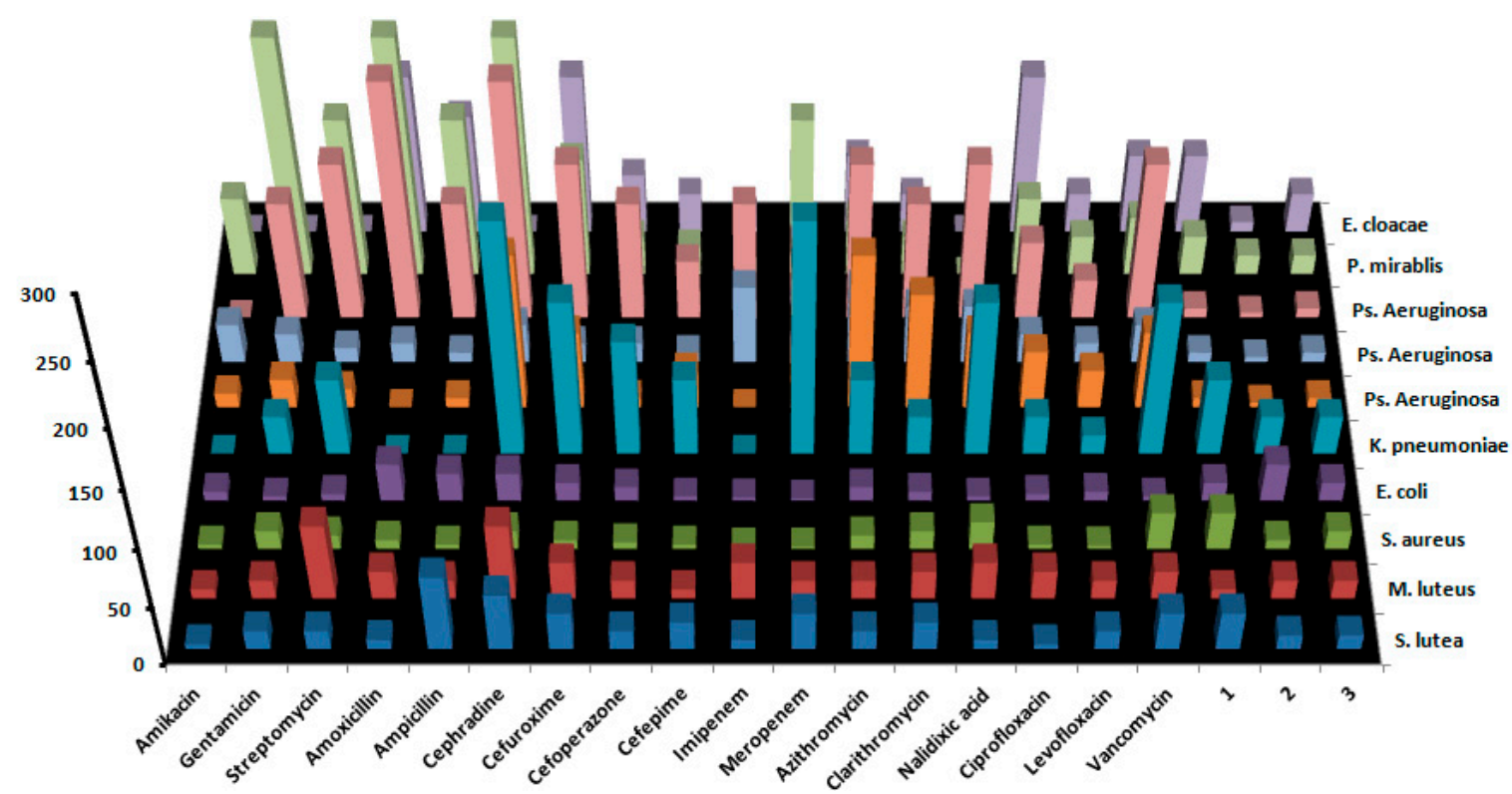

Figure 11. Overview of the antibacterial test showing Minimum Inhibitory Concentrations (MIC) in $\mu \mathrm{g} / \mathrm{mL}$, thus lowest values corresponding to the most active compounds.

\subsection{Molecular Docking Studies}

The analysis of the docking results revealed that among all seven targets, only thymidylate kinase (TMK) from P. aeruginosa showed good binding affinity and docking interactions with studied complexes. The results of the docking scores of control inhibitor and silver complexes against the target proteins are mentioned in the Table 3. Figure 12D presents the alignment of different silver complexes in the active site of TMK. As shown in the Figure 12A-C, all the complexes fit well into the active site of TMK. The coordinates of these compounds overlap in the crystal structure of the template plate, mimicking some of its interactions with the macromolecule.

Table 3. Root-mean-square deviation (RMSD) and predicted binding affinity (docking scores in $\mathrm{kcal} / \mathrm{mol}$ ) of control inhibitor and silver complexes against target proteins.

\begin{tabular}{|c|c|c|c|c|c|}
\hline \multirow{3}{*}{ PDB ID Codes } & & & \multicolumn{3}{|c|}{ Docking Scores } \\
\hline & \multicolumn{2}{|l|}{ RMSD of Control Ligand } & \multicolumn{3}{|c|}{ Silver (I) Complexes } \\
\hline & (Å) & Control Ligand & 1 & 2 & 3 \\
\hline 1IYL & 1.85 & -11.6752 & -7.224 & -10.1026 & -7.7626 \\
\hline 1BNA & - & - & -5.7922 & -7.2206 & -4.3620 \\
\hline 3FYV & 1.23 & -8.4286 & -6.8618 & -9.6077 & -5.3467 \\
\hline 3UWK & 0.9 & -10.9856 & -8.1865 & -11.4224 & -6.2362 \\
\hline $4 \mathrm{HOF}$ & 1.5 & -8.6736 & -5.9142 & -7.8969 & -4.9028 \\
\hline 4URM & 1.9 & -9.4327 & -6.7318 & -8.0604 & -4.881 \\
\hline $4 \mathrm{H} 2 \mathrm{M}$ & 2.0 & -10.6792 & -5.7233 & -9.2959 & -4.8587 \\
\hline
\end{tabular}



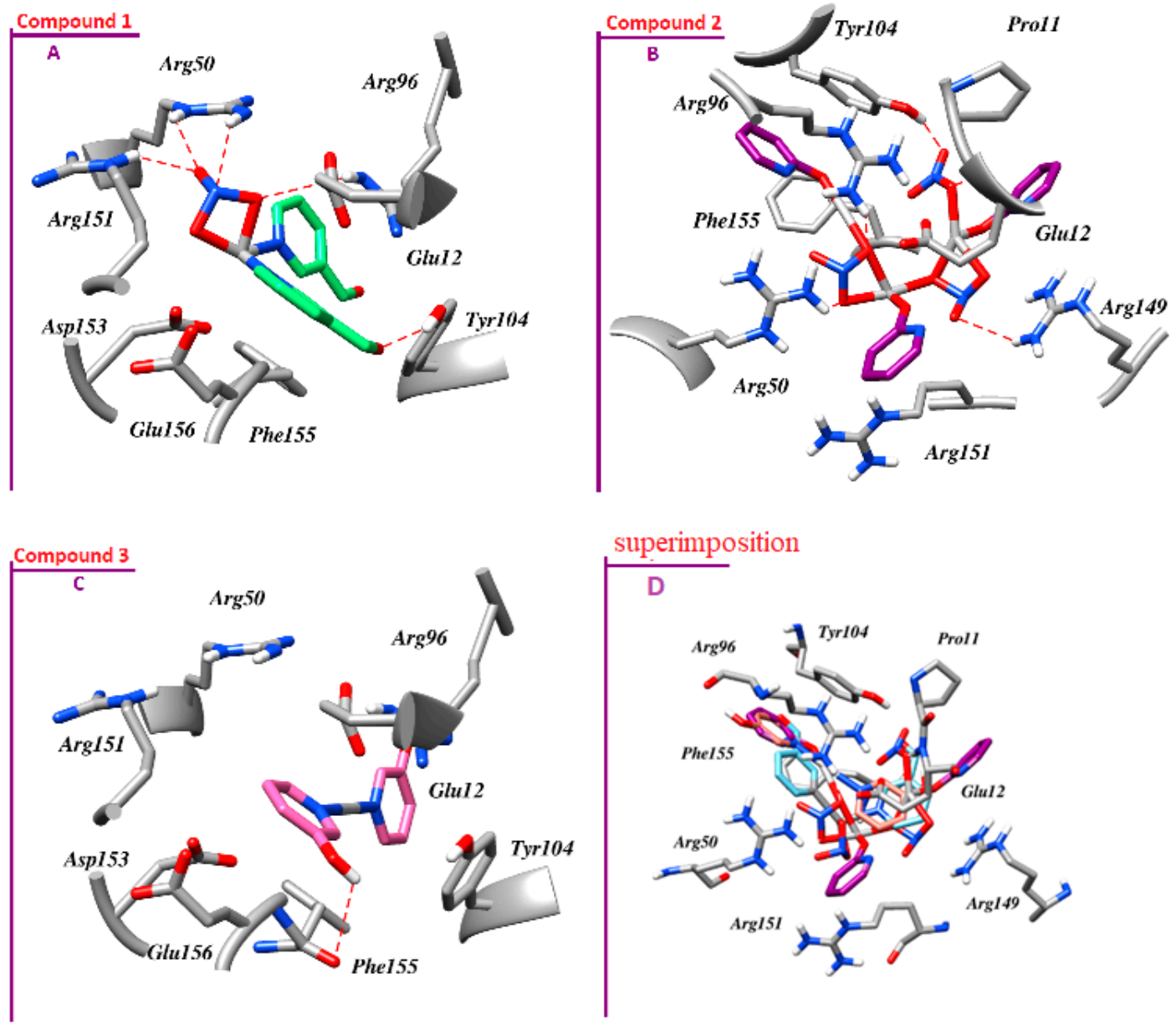

Figure 12. Binding patterns of (A) Complex 1, (B) Complex 2, and (C) Complex 3 with thymidylate kinase (TMK) of P. aeruginosa demonstrated from the top ranked dock pose. Red dashed lines represent H-bonds, while (D) presents the superimposition of all the compounds.

The binding mode of complex 1 with thymidylate kinase displayed number of prominent interactions including hydrophobic, hydrophilic, salt bridges, and $\pi$ - stacking interactions. Figure $12 \mathrm{~A}$ presented that $\mathrm{O}_{3}$ of the nitrate anion that directly ligated to the silver metal involved in hydrogen bond interaction with the side chain of Arg50 (2.73 and $2.95 \AA)$, $\operatorname{Arg} 96$ (3.23 $\AA$ ), and $\operatorname{Arg} 151$ (2.85 $\AA)$, respectively. While Tyr104 mediate strong hydrogen bond interaction with the carbonyl of pyridine-3-carboxaldehyde at a distance of $2.07 \AA$. The hydrophobic contact of pyridine ring with Glu12, Arg96, Phe155, and Glu156 might also contribute in the observed activity of this complex. Further protein-ligand interactions are stabilized by the formation of a salt bridge between complex and Glu12 and Asp153. Moreover, the geometry of the silver metal interaction retained by making contact with Asp153 at a distance of $2.78 \AA$.

In case of most active complex 2 , a network of strong hydrogen bond interactions with the residues of the active site of TMK has been observed that rationalize the inhibitory potential of the complex. The nitrate ion of the complex involved in three hydrogen bond interactions with Tyr104, side chain of Glu12, and Arg96 at a distance of 1.88, 2.19, and 2.46 ̊, respectively. Both of the nitrate ions that ligated with silver metal mediated bidentate hydrogen bond interactions with the residues Glu12 (3.02 $\AA$ ), $\operatorname{Arg} 50(2.99 \AA), \operatorname{Arg} 96(2.66 \AA), \operatorname{Arg} 149$ (2.80 and $2.88 \AA)$, and Glu156 (3.41 ̊̊). The hydrophobic contact of pyridone rings with the hydrophobic patch of Pro11, Ala100, Tyr104, Ala146, Arg151, Phe155, and Phe163 provided further anchorage to the active site. Complex 2 was further stabilized by special type of electrostatic interactions i.e., salt bridges between pyridone of the complex with Glu12, Asp153, and Glu156 (Figure 12B). 
In contrast to complexes $\mathbf{1}$ and 2, complex 3 (Figure 12C) mainly stabilized by hydrophobic interactions with Glu12, Ala100, Tyr104, Phe155, and Glu156. Additionally, the contacts were further stabilized by hydrophilic interactions between Glu12 and Phe155 with 3-hydroxypyridine at a distance of 3.30 and $31.9 \AA$, respectively.

\section{Conclusions}

Three Ag(I) complexes with pyridine ligands were synthesized and well characterized using X-ray single crystal diffraction analysis, elemental analysis and NMR spectra. The solid state structure of $\left[\mathrm{Ag}\left(2 \text {-pyridone) } \mathrm{NO}_{3}\right]_{\mathrm{n}}\right.$ is peculiar and best understood using network topology analysis giving the unusual ins-net. Their antimicrobial properties were compared with 17 antibiotics. [Ag(2-pyridone) $\left.\mathrm{NO}_{3}\right]_{\mathrm{n}}$ has specific activity against three clinically isolated strains of Ps. Aeruginosa compared to the tested antibiotics. This group of silver(I) pyridine complexes have relatively high biological activity against a broad spectrum of MDR (multi drug resistance) and ATCC standard bacteria as well as the fungus $C$. albicans. We hope to find promising substances to be used in wound dressing applications. Also, molecular packing analyses for complexes 1-3 were performed with the aid of Hirshfeld analysis. The net charges at silver atom are $0.6222,0.7284$, and 0.6852 instead of 1.0000 due to the interactions with the ligand groups coordinating it. The molecular docking of the studied complexes shows several types of interactions with the pocket including hydrophilic, hydrophobic, salt bridges, and $\pi$ - stacking interactions.

Supplementary Materials: The following are available online at http://www.mdpi.com/2076-3417/10/14/4853/s1, Figures S1-S3: ${ }^{1} \mathrm{H}$ and ${ }^{13} \mathrm{C}$ NMR spectra of complexes 1-3. Figure S4: Distorted tetrahedral coordination of the silver atoms in $\left[\mathrm{Ag}\left(2 \text {-pyridone) } \mathrm{NO}_{3}\right]_{n}\right.$. Figure S5: Hydrogen bond interactions. Figure S6: X-ray structure with atom numbering for complexes 1-3. Tables S1-S4: X-ray crystal data for the complexes 1-3.

Author Contributions: Conceptualization, A.M.A.B. and S.M.S.; data curation, A.M.A.B., A.B., J.H.A., M.M.S., and Z.U.-H.; formal analysis, J.H.A., M.M.S., Z.U.-H., and S.M.S.; funding acquisition, A.B.; investigation, S.M.S.; methodology, M.M.S. and S.M.S.; software, J.H.A. and Z.U.-H.; supervision, S.M.S.; writing-original draft, A.M.A.B., A.B., Z.U.-H., and S.M.S.; writing-review and editing, A.M.A.B., A.B., and S.M.S. All authors have read and agreed to the published version of the manuscript.

Funding: The research was funded by King Saud University, Researchers Supporting Project Number (RSP-2020/64).

Acknowledgments: The authors would like to extend their sincere appreciation to Researchers Supporting Project Number (RSP-2020/64), King Saud University, Riyadh, Saudi Arabia.

Conflicts of Interest: The authors declare no conflicts of interest.

\section{References}

1. Savic, N.D.; Milivojevic, D.R.; Glisic, B.D.; Ilic-Tomic, T.; Veselinovic, J.; Pavic, A.; Vasiljevic, B.; Nikodinovic-Runic, J.; Djuran, M.I. A comparative antimicrobial and toxicological study of gold(iii) and silver(i) complexes with aromatic nitrogen-containing heterocycles: Synergistic activity and improved selectivity index of $\mathrm{Au}(\mathrm{iii}) / \mathrm{Ag}(\mathrm{i})$ complexes mixture. Rsc Adv. 2016, 6, 13193-13206. [CrossRef]

2. Marchetti, F.; Palmucci, J.; Pettinari, C.; Pettinari, R.; Scuri, S.; Grappasonni, I.; Cocchioni, M.; Amati, M.; Lelj, F.; Crispini, A. Linkage Isomerism in Silver Acylpyrazolonato Complexes and Correlation with Their Antibacterial Activity. Inorg. Chem. 2016, 55, 5453-5466. [CrossRef] [PubMed]

3. Jiang, Y.; Zhu, C.F.; Zheng, Z.; He, J.B.; Wang, Y. Synthesis, characterization and antibacterial activity of a biocompatible silver complex based on 2,2'-bipyridine and 5-sulfoisophthalate. Inorg. Chim. Acta 2016, 451, 143-147. [CrossRef]

4. Glisic, B.D.; Senerovic, L.; Comba, P.; Wadepohl, H.; Veselinovic, A.; Milivojevic, D.R.; Djuran, M.I.; Nikodinovic-Runic, J. Silver(I) complexes with phthalazine and quinazoline as effective agents against pathogenic Pseudomonas aeruginosa strains. J. Inorg. Biochem. 2016, 155, 115-128. [CrossRef]

5. Fiori, A.T.M.; Nakahata, D.H.; Cuin, A.; Lustri, W.R.; Corbi, P.P. Synthesis, crystallographic studies, high resolution mass spectrometric analyses and antibacterial assays of silver(I) complexes with sulfisoxazole and sulfadimethoxine. Polyhedron 2017, 121, 172-179. [CrossRef] 
6. Cardoso, J.M.S.; Galvao, A.M.; Guerreiro, S.I.; Leitao, J.H.; Suarez, A.C.; Carvalho, M. Antibacterial activity of silver camphorimine coordination polymers. Dalton Trans. 2016, 45, 7114-7123. [CrossRef]

7. Alisir, S.H.; Dege, N. A new antibacterial silver(I) complex incorporating 2,5-di-methyl-pyrazine and the anti-inflammatory diclofenac. Acta Crystallograp. C 2016, 72, 947-951. [CrossRef]

8. Adamski, A.; Fik, M.A.; Kubicki, M.; Hnatejko, Z.; Gurda, D.; Fedoruk-Wyszomirska, A.; Wyszko, E.; Kruszka, D.; Dutkiewicz, Z.; Patroniak, V. Full characterization and cytotoxic activity of new silver(i) and copper(i) helicates with quaterpyridine. New J. Chem. 2016, 40, 7943-7957. [CrossRef]

9. Rigamonti, L.; Cotton, C.; Nava, A.; Lang, H.; Ruffer, T.; Perfetti, M.; Sorace, L.; Barra, A.L.; Lan, Y.H.; Wernsdorfer, W.; et al. Diamondoid Structure in a Metal-Organic Framework of $\mathrm{Fe}_{4}$ Single-Molecule Magnets. Chem. Eur. J. 2016, 22, 13705-13714. [CrossRef]

10. Jaros, S.W.; da Silva, M.; Krol, J.; Oliveira, M.C.; Smolenski, P.; Pombeiro, A.J.L.; Kirillov, A.M. Bioactive Silver-Organic Networks Assembled from 1,3,5-Triaza-7-phosphaadamantane and Flexible Cyclohexanecarboxylate Blocks. Inorg. Chem. 2016, 55, 1486-1496. [CrossRef]

11. Medici, S.; Peana, M.; Crisponi, G.; Nurchi, V.M.; Lachowicz, J.I.; Remelli, M.; Zoroddu, M.A. Silver coordination compounds: A new horizon in medicine. Coord. Chem. Rev. 2016, 327, 349-359. [CrossRef]

12. Storm-Versloot, M.N.; Vos, C.G.; Ubbink, D.T.; Vermeulen, H. Cochrane Database of Systematic Reviews. 2010.

13. McDonnell, G.; Russell, A.D. Antiseptics and disinfectants: Activity, action, and resistance. Clin. Microbiol. Rev. 1999, 12, 147-179. [CrossRef] [PubMed]

14. Farrer, N.J.; Sadler, P.J. Medicinal inorganic chemistry: State of the art, new trends, and a vision of the future. Bioinorg. Med. Chem. 2011, 2011, 1-47.

15. Dai, T.; Huang, Y.Y.; K Sharma, S.; T Hashmi, J.; B Kurup, D.; R Hamblin, M. Topical antimicrobials for burn wound infections. Recent Pat. Anti Infect. Drug Discov. 2010, 5, 124-151. [CrossRef] [PubMed]

16. Heyneman, A.; Hoeksema, H.; Vandekerckhove, D.; Pirayesh, A.; Monstrey, S. The role of silver sulphadiazine in the conservative treatment of partial thickness burn wounds: A systematic review. Burns 2016, 42, 1377-1386. [CrossRef] [PubMed]

17. Savić, N.D.; Vojnovic, S.; Glišić, B.Đ.; Crochet, A.; Pavic, A.; Janjić, G.V.; Pekmezović, M.; Opsenica, I.M.; Fromm, K.M.; Nikodinovic-Runic, J.; et al. Mononuclear silver (I) complexes with 1, 7-phenanthroline as potent inhibitors of Candida growth. Europ. J. Med. Chem. 2018, 156, 760-773. [CrossRef]

18. Mujahid, M.; Trendafilova, N.; Arfa-Kia, A.F.; Rosair, G.; Kavanagh, K.; Devereux, M.; Walsh, M.; McClean, S.; Creaven, B.S.; Georgieva, I. Novel silver (I) complexes of coumarin oxyacetate ligands and their phenanthroline adducts: Biological activity, structural and spectroscopic characterisation. J. Inorg. Biochem. 2016, 163, 53-67. [CrossRef]

19. Soliman, S.M.; Badr, A.M.A. Synthesis, structure and Hirshfeld analysis of the potent antimicrobial [Ag(4-bromopyrazole $)_{2} \mathrm{ClO}_{4}$ ] complex. Polyhedron 2019, 171, 323-329. [CrossRef]

20. Andrejević, T.P.; Nikolić, A.M.; Glišić, B.Đ.; Wadepohl, H.; Vojnovic, S.; Zlatović, M.; Petković, M.; Nikodinovic-Runic, J.; Opsenica, I.M.; Djuran, M.I. Synthesis, structural characterization and antimicrobial activity of silver (I) complexes with 1-benzyl-1H-tetrazoles. Polyhedron 2018, 154, 325-333.

21. Eckhardt, S.; Brunetto, P.S.; Gagnon, J.; Priebe, M.; Giese, B.; Fromm, K.M. Nanobio silver: Its interactions with peptides and bacteria, and its uses in medicine. Chem. Rev. 2013, 113, 4708-4754. [CrossRef]

22. Russell, A.D.; Hugo, W.B. 7 antimicrobial activity and action of silver. Prog. Med. Chem. 1994, 31, 351-370. [PubMed]

23. Liau, S.Y.; Read, D.C.; Pugh, W.J.; Furr, J.R.; Russell, A.D. Interaction of silver nitrate with readily identifiable groups: Relationship to the antibacterialaction of silver ions. Letters Appl. Microbiol. 1997, 25, 279-283. [CrossRef] [PubMed]

24. Soliman, S.M.; Albering, J.H.; Barakat, A. Unexpected formation of polymeric silver (I) complexes of azine-type ligand via self-assembly of Ag-salts with isatin oxamohydrazide. R. Soc. Open Sci. 2018, 5, 180434. [CrossRef]

25. Abu-Youssef, M.; Soliman, S.; Sharaf, M.; Albering, J.; Öhrström, L. Topology analysis reveals supramolecular organisation of 96 large complex ions into one geometrical object. Cryst. Eng. Comm. 2016, 18, 1883-1886. [CrossRef]

26. Ivanova, B.; Spiteller, M. AgI and ZnII complexes with possible application as NLO materials-Crystal structures and properties. Polyhedron 2011, 30, 241-245. [CrossRef] 
27. Bowmaker, G.; Effendy, A.; Nitiatmodjo, M.; Skelton, B.W.; White, A.H. Syntheses and structures of some adducts of silver(I) oxyanion salts with some 2-N,O-donor-substituted pyridine bases. Inorg. Chim. Acta 2005, 358, 4327-4341. [CrossRef]

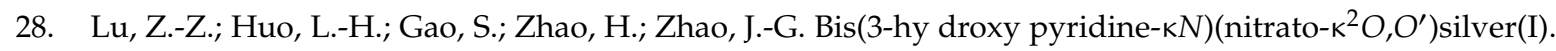
Acta Cryst. 2005, E61, m1386-m1388.

29. O'Keeffe, M.; Peskov, M.A.; Ramsden, S.; Yaghi, O.M. The Reticular Chemistry Structure Resource (RCSR) Database of, and Symbols for, Crystal Nets. Acc. Chem. Res. 2008, 41, 1782-1789. [CrossRef]

30. Öhrström, L. Let's Talk about MOFs-Topology and Terminology of Metal-Organic Frameworks and Why We Need Them. Crystals 2015, 5, 154.

31. Ohrstrom, L. Designing, Describing and Disseminating New Materials by using the Network Topology Approach. Chem. Eur. J. 2016, 22, 13758-13763. [CrossRef]

32. Spackman, M.A.; McKinnon, J.J. Fingerprinting intermolecular interactions in molecular crystals. Cryst. Eng. Comm. 2002, 4, 378-392. [CrossRef]

33. McKinnon, J.J.; Jayatilaka, D.; Spackman, M.A. Towards quantitative analysis of intermolecular interactions with Hirshfeld surfaces. Chem. Commun. 2007, 37, 3814-3816. [CrossRef]

34. Spackman, M.A.; McKinnon, J.J.; Jayatilaka, D. Electrostatic potentials mapped on Hirshfeld surfaces provide direct insight into intermolecular interactions in crystals. Cryst. Eng. Comm. 2008, 10, 377-388. [CrossRef]

35. Spackman, M.A.; Jayatilaka, D. Hirshfeld surface analysis. Cryst. Eng. Comm. 2009, 11, 19-32. [CrossRef]

36. Hirshfeld, F.L. Bonded-atom fragments for describing molecular charge densities. Theor. Chim. Acta. 1977, 44, 129-133. [CrossRef]

37. Martin, A.D.; Hartlieb, K.J.; Sobolev, A.N.; Raston, C.L. Hirshfeld surface analysis of substituted phenols. Cryst. Growth. Des. 2010, 10, 5302-5306. [CrossRef]

38. SADABS, version 2.10; University of Göttingen: Göttingen, Germany, 2003.

39. APEX2; Bruker Nonius BV: Delft, The Netherlands, 2004.

40. SHELXTL; Version 6.14; Bruker AXS Inc.: Madison, WI, USA, 2003.

41. Turner, M.J.; McKinnon, J.J.; Wolff, S.K.; Grimwood, D.J.; Spackman, P.R.; Jayatilaka, D.; Spackman, M.A. Crystal Explorer17, 2017, University of Western Australia. Available online: http://hirshfeldsurface.net (accessed on 12 June 2017).

42. Glendening, E.D.; Reed, A.E.; Carpenter, J.E.; Weinhold, F. NBO; Version 3.1; CI, University of Wisconsin: Madison, WI, USA, 1998.

43. Frisch, M.J.; Trucks, G.W.; Schlegel, H.B.; Scuseria, G.E.; Robb, M.A.; Cheeseman, J.R.; Scalmani, G.; Barone, V.; Mennucci, B.; Petersson, G.A.; et al. Gaussian 09, Reversion B.01; Gaussian, Inc.: Wallingford, CT, USA, 2010.

44. Abu-Youssef, M.A.M.; Soliman, S.M.; Langer, V.; Gohar, Y.M.; Hasanen, A.A.; Makhyoun, M.A.; Zaky, A.H.; Öhrström, L.R. Synthesis, Crystal Structure, Quantum Chemical Calculations, DNA Interactions, and Antimicrobial Activity of [Ag(2-amino-3-methylpyridine) $\left.{ }_{2}\right] \mathrm{NO}_{3}$ and [Ag(pyridine-2-carboxaldoxime) $\left.\mathrm{NO}_{3}\right]$. Inorg. Chem. 2010, 49, 9788-9797. [CrossRef]

45. Sogabe, S.; Masubuchi, M.; Sakata, K.; Fukami, T.A.; Morikami, K.; Shiratori, Y.; Ebiike, H.; Kawasaki, K.; Aoki, Y.; Shimma, N.; et al. Crystal structures of Candida albicans N-myristoyltransferase with two distinct inhibitors. Chem. Biol. 2002, 9, 1119-1128. [CrossRef]

46. G-Dayanandan, N.; Paulsen, J.L.; Viswanathan, K.; Keshipeddy, S.; Lombardo, M.N.; Zhou, W.; Lamb, K.M.; Sochia, A.E.; Alverson, J.B.; Priestley, N.D.; et al. Propargyl-linked antifolates are dual inhibitors of Candida albicans and Candida glabrata. J.Med. Chem. 2014, 57, 2643-2656. [CrossRef]

47. Oefner, C.; Parisi, S.; Schulz, H.; Lociuro, S.; Dale, G.E. Inhibitory properties and X-ray crystallographic study of the binding of AR-101, AR-102 and iclaprim in ternary complexes with NADPH and dihydrofolate reductase from Staphylococcus aureus. Acta Cryst. D. 2009, 65, 751-757. [CrossRef]

48. Lu, J.; Patel, S.; Sharma, N.; Soisson, S.M.; Kishii, R.; Takei, M.; Fukuda, Y.; Lumb, K.J.; Singh, S.B. Structures of kibdelomycin bound to Staphylococcus aureus GyrB and ParE showed a novel U-shaped binding mode. Acs Chem. Biol. 2014, 9, 2023-2031. [CrossRef]

49. Drew, H.R.; Wing, R.M.; Takano, T.; Broka, C.; Tanaka, S.; Itakura, K.; Dickerson, R.E. Structure of a B-DNA dodecamer: Conformation and dynamics. Proc. Natl. Acad. Sci. USA 1981, 78, 2179-2183. [CrossRef]

50. Choi, J.Y.; Plummer, M.S.; Starr, J.; Desbonnet, C.R.; Soutter, H.; Chang, J.; Miller, J.R.; Dillman, K.; Miller, A.A.; Roush, W.R. Structure guided development of novel thymidine mimetics targeting Pseudomonas aeruginosa thymidylate kinase: From hit to lead generation. J. Med. Chem. 2012, 55, 852-870. [CrossRef] [PubMed] 
51. Zhu, W.; Zhang, Y.; Sinko, W.; Hensler, M.E.; Olson, J.; Molohon, K.J.; Lindert, S.; Cao, R.; Li, K.; Wang, K.; et al. Antibacterial drug leads targeting isoprenoid biosynthesis. Proc. Natl. Acad. Sci. USA 2013, 110, 123-128. [CrossRef] [PubMed]

52. Molecular Operating Environment (MOE); Chemical Computing Group ULC: Montreal, QC, Canada, 2018.

53. Halgren, T.A. Merck molecular force field. I. Basis, form, scope, parameterization, and performance of MMFF94. J. Comput. Chem. 1996, 17, 490-519. [CrossRef]

54. Allen, F.H.; Motherwell, W.D.S.; Raithby, P.R.; Shields, G.P.; Taylor, R. Systematic analysis of the probabilities of formation of bimolecular hydrogen-bonded ring motifs in organic crystal structures. New J. Chem. 1999, 23, 25-34. [CrossRef]

55. Carlucci, L.; Ciani, G.; vonGudenberg, D.W.; Proserpio, D.M.; Sironi, A. Self-assembly of a three-dimensional network from two-dimensional layers via metallic spacers: The $(3,4)$-connected frame of $\left[\mathrm{Ag}_{3}(\mathrm{hmt})_{2}\right]\left[\mathrm{ClO}_{4}\right]_{3} \cdot 2 \mathrm{H}_{2} \mathrm{O}(\mathrm{hmt}=$ hexamethylenetetramine). Chem. Commun. 1997, 6, 631-632. [CrossRef]

56. Yang, H.W.; Craven, B.M. Charge Density Study of 2-Pyridone. Acta Cryst. B 1998, 54, 912-920. [CrossRef] [PubMed]

57. Hejazi, S.A.; Osman, O.I.; Alyoubi, A.O.; Aziz, S.G.; Hilal, R.H. The Thermodynamic and Kinetic Properties of 2-Hydroxypyridine/2-Pyridone Tautomerization: A Theoretical and Computational Revisit. Int. J. Mol. Sci. 2016, 17, 1893. [CrossRef] [PubMed]

58. Kasuga, N.C.; Yamamoto, R.; Hara, A.; Amano, A.; Nomiya, K. Molecular design, crystal structure, antimicrobial activity and reactivity of light-stable and water-soluble Ag-O bonding silver(I) complexes, dinuclear silver(I) N-acetylglycinate. Inorg. Chim. Acta 2006, 359, 4412-4416. [CrossRef]

59. Barreiro, E.; Casas, J.S.; Couce, M.D.; Sanchez, A.; Seoane, R.; Sordo, J.; Varela, J.M.; Vazquez-Lopez, E.M. Synthesis and antimicrobial activities of silver(I) 3-(substituted phenyl)sulfanylpropenoates. Europ. J. Med. Chem. 2008, 43, 2489-2497. [CrossRef]

60. Abu-Youssef, M.A.M.; Dey, R.; Gohar, Y.; Massoud, A.A.; Ohrstrom, L.; Langer, V. Synthesis and Structure of Silver Complexes with Nicotinate-Type Ligands Having Antibacterial Activities against Clinically Isolated Antibiotic Resistant Pathogens. Inorg. Chem. 2007, 46, 5893-5903. [CrossRef] [PubMed] 